\title{
Common Reed as a Renewable Energy Resource for Pellet Production
}

\author{
Vasiliy Kostin ${ }^{1}$, Vladimir Kochetkov ${ }^{2, *}$, Natalya Sokolova², and Ivan Vasenev ${ }^{3}$ \\ ${ }^{1}$ Volzhsky Polytechnic Institute (branch) of Federal State Budget Educational Institution of Higher \\ Education Volgograd State Technical University, Department of Mechanics, 404121 Volzhsky, \\ Russian Federation \\ ${ }^{2}$ Volzhsky Polytechnic Institute (branch) of Federal State Budget Educational Institution of Higher \\ Education Volgograd State Technical University Of chemical technology of polymers and industrial \\ ecology, 404121 Volzhsky, Russian Federation \\ ${ }^{3}$ Russian State Agrarian University - Moscow Timiryazev Agricultural Academy, Department of \\ Ecology, 127550 Moscow, Russian Federation
}

\begin{abstract}
Renewable reed biomass has traditionally been used for various purposes. Currently, an energy-dependent society is returning to the use of natural energy sources. The paper is devoted to the study of reed reserves in the Lower Volga region, production technology, and quality assessment of pellets from it. Reed mowing with further production of fuel pellets from biomass will not only provide the local population or small enterprises with energy but also solve a number of environmental problems. The main environmental problem is the high fire hazard of reed beds. The main characteristics of the pellets that have been investigated by the authors are humidity, ash content, calorific value, and the composition of the ash residue. When granulating shredded cormophytic biomass, the main process parameter affecting the fuel pellet quality is the moisture content of the raw materials, which has been determined experimentally. To improve the consumer properties of the granules, binders were also experimentally selected. Binders should not reduce the calorific value and impair the composition of the ash residue
\end{abstract}

\section{Introduction}

Common reed is widespread almost everywhere in Europe, except for desert and the Arctic. From the economic point of view, the reed is a weed infesting all agricultural crops on irrigated lands, whereby it causes significant damage [1, 3].

In spring and summer, reed beds create an increased fire hazard. In absolutely most cases in the reed beds, fire is caused by the anthropogenic factor. The fire that has arisen in the reed beds especially in dry and windy conditions quickly becomes uncontrolled. In spring, the reed fires are systematic and massive [1].

Proper science-based control over the reed biomass can significantly reduce the risk of landscape fires and bring economic benefits from the production of commercial goods [1].

${ }^{*}$ Corresponding author: vg.kochetkov@mail.ru 
One of the promising ways to solve the issue of utilizing rapidly growing reed biomass is to use it as biofuel for small-size power plants, e.g., district boiler houses, peasant farms, small industrial enterprises, or private households. As a biofuel, it is advisable to produce pellets (fuel granules) from cormophytic reed biomass [1].

Recently, the demand for fuel pellets made of non-wood raw materials, including reed has been growing especially in regions suffering from the lack of other resources - wood, coal.

Producing fuel pellets from wood waste is widespread in many world countries. In 2018, almost 36 million tons of wood fuel pellets were globally produced and by 2028, according to INFOBIO IAA experts' estimates, this volume would increase 2.5 times [2].

The Volzhsky Polytechnic Institute scientists have studied the possible operational reserves of reed growing in the entire Volgograd region and particularly in the VolgaAkhtuba Floodplain (involving the territories of two administrative districts of the Astrakhan region). The most suitable technique to determine the productivity of the reed fields and evaluate the probable harvest is the plot harvesting [3]. In the reed raw materials granulation, one of the most important characteristics is the moisture content, which has been determined experimentally.

Granulation can be performed with and without binders, however, the use of binders allows improving the consumer properties of reed pellets. Binders have also been experimentally selected.

To evaluate the finished products, i.e. reed biomass pellets, parameters such as pellet moisture, calorific value, ash content, and ash residue composition should be determined, since it is these characteristics that affect either the operational or ecological parameters of the finished product. These parameters have also been determined by the paper authors in the experiments.

\section{Estimating the reserves of reed raw materials in the Volga- Akhtuba floodplain and the entire Volgograd region}

Locating reed beds is an important task for determining the biological and operational reed resources and performing the feasibility study of its further rational use.

To study the operational reed reserves of the Volgograd region, requests have been drawn up and sent to agencies interested in reducing the fire hazard in reed growing areas, as well as natural regional parks and forest ranger stations. Based on the data obtained, a preliminary generalized analysis has been conducted for the reed beds in certain regional districts.

Reed beds growing in the Volga-Akhtuba Floodplain have been studied in more detail. Three districts of the Volgograd region-the Central Akhtubinsky, Leninsky, and Svetloyarsky ones, and two administrative districts of the Astrakhan region - Akhtubinsky and Chernoyarsky ones have been investigated. All these districts are fully or partially located in the floodplain.

To fulfill the tasks set, a field expedition was preliminarily arranged, the objective of which was to locate the commercial reed beds, determine the harvesting boundaries and the crop productivity, and estimate reserves of these areas and lands. In the course of field studies, the location of commercial beds and lands was identified. The beds and lands located have been plotted on topographic maps.

The work was performed from December 15, 2015 to February 1, 2016. Carrying out location work is most feasible in this period, since reed beds are easy to identify by the color, which is specific for this season; in winter, they are most researchable, especially after a certain subzero (Celsius) temperature period that causes freezing of the soil and forming a stable strong ice cover on the water surface. Industrial harvesting is performed in 
winter, therefore, the study of operational reed reserves and analysis of their condition from the point of view of suitability to produce solid biofuel have been carried out just at that time.

The task of locating commercial reed beds and determining the operational reed reserves in the Volgograd and Astrakhan regions has been divided into two stages.

The first stage is locating commercial reed beds as such. The search expedition aimed at locating reed beds has used photo equipment and the public Internet resources Yandex Maps and google.ru/maps that allow accurately tracking the commercial reed beds identified. To correlate the administrative attribution of reed beds, cadastral maps of settlements or notable geographical objects have also been used. To determine the reed bed area, the following procedure was applied: the survey region was determined on a map using Internet resources and the scale was increased to sizes allowing to identify reed beds on the map. The image was converted into the Compass graphic editor, in which the reed bed perimeter was outlined with further determining the resulting flat figure area in $\mathrm{mm} 2$. Since the electronic map has a scale indicator, a reference square has been constructed in this scale, the area of which is easy to determine in true $\left(\mathrm{m}^{2}\right)$ and relative units using the Compass graphics editor [3]. The second stage is a field study aimed at determining the operational reed reserves. At the second stage, trips were made to the reed beds located at the first stage and operational reed reserves were determined using the plot harvesting technique.

In [3], a procedure for defining the reed bed productivity in site investigations is described. Plots of $1 \times 1 \mathrm{~m}$ in size were laid in a straight line in a reed bed. At these plots, control mowing was performed and to calculate the reserves, the productivity determined as a result of the control mowing was multiplied by the area of the commercial harvesting. For this purpose, the reed beds with a productivity of more than $3 \mathrm{t} /$ ha were considered commercial ones [4]. However, this method has shortcomings: laying straight routes in reed beds is very difficult even using special equipment; the number of plots should be large to reduce the error; the control mowing error increases with decreasing plot size. For this study, it has been decided to use a typical plot sampling within a reed bed. The number of plots within the bed varied from 5 to 7 . This method allows considering the reed bed plots with the highest, average, and lowest yield without the need to lay certain routes in the beds, which is very difficult in the course of mowing, since it is impossible to clearly define the location and ties in dense and high reed beds. The plot dimensions were $5 \times 5 \mathrm{~m}$. The reed was mowed using a weed whacker to ensure the lack of unmown reeds inside the perimeter. All reed mowed at the plot was collected and weighed using electronic scales. The measurement results were recorded in a logbook specifying the place and time of measurement. Sampling has also been made to determine the moisture content of reed in the beds studied in the research. To do this, the sampled material was placed in an airtight valved bag; in addition, reed material was sampled in an amount of 2-3 $\mathrm{kg}$ for further processing into fuel pellets.

During the expeditions, an area of about $10,000 \mathrm{~km}^{2}$ was surveyed, on which more than 16,000 ha of reed beds were identified (despite the entire Volga-Akhtuba Floodplain area is about 20,000 $\mathrm{km}^{2}$ ). The average yield of mowed and dry biomass is 5.7 and $4.6 \mathrm{t} / \mathrm{ha}$, respectively, as can be seen from table 1 . When comparing the areas occupied by reed beds with a cadastral map, we may conclude that most of the beds are located on the territory of settlements and agricultural lands [3].

The production of reed fuel pellets requires the moisture content of the feedstock (mowed reed) to be within certain limits. Otherwise, the initial reed biomass would require drying or moisturizing. From a technological point of view, drying is a much more complicated and costly operation. According to the results of field studies in which samples 
have been taken to determine the moisture content, in most cases, the moisture content of reed biomass is quite suitable to produce the fuel pellets without drying (Table 1).

Table 1. Annual reed harvesting

\begin{tabular}{|c|c|c|c|c|}
\hline \multirow{2}{*}{ Research Area } & \multirow{2}{*}{ Area, ha } & \multirow{2}{*}{$\begin{array}{c}\text { Moisture } \\
\text { Content, \% }\end{array}$} & $\begin{array}{c}\text { Productivity, } \\
\text { t/ha }\end{array}$ & $\begin{array}{c}\text { Annual } \\
\text { Harvesting, t }\end{array}$ \\
\cline { 5 - 5 } & & & \multicolumn{2}{|c|}{ Dry biomass } \\
\hline Bolshoy Liman & 345 & 9.82 & 5.340 & 1842 \\
\hline Novostroyka & 86 & 7.18 & 2.697 & 232 \\
\hline Stepan Razin & 216 & 8.43 & 2.616 & 565 \\
\hline Gusiny Liman & 329 & 8.43 & 2.454 & 807 \\
\hline MTF & 92 & 8.43 & 2.575 & 237 \\
\hline Zapornoe Lake & 37 & 13.3 & 8.322 & 308 \\
\hline Repino & 45 & 13.3 & 3.082 & 139 \\
\hline Zhestkovo Lake & 50 & 13.3 & 3.167 & 158 \\
\hline Khutor Talovy & 187 & 39.18 & 9.113 & 1704 \\
\hline Sukhodol & 40 & 39.18 & 5.234 & 209 \\
\hline Volzhsky Industrial Area & 179 & 9.51 & 7.650 & 1369 \\
\hline Average value & 16,357 & 14.62 & 4.606 & 75,340 \\
\hline
\end{tabular}

The only sample taken in the Khutor Talovy area had increased water content. This can be explained by either measurement error (outlier) or, more likely, the adverse atmospheric effects (fog and fine rain during research).

The calculation results entirely confirm the previously accepted hypothesis of average reed yield, according to which this value is supposed to be within 4.22 to $7.18 \mathrm{t} / \mathrm{ha}$.

The results can be considered reliable and used to estimate the reed yield and possible harvesting in the territories surveyed. The forecasted total value of possible harvesting for all explored commercial beds should be within 75 to 85 thousand tons, which is quite enough to power, e.g., an enterprise for processing agricultural products or arrange the production of reed pellets for sale on the solid biofuel market.

To track the reed biomass rehabilitation in the vegetative period, monitoring of the reed biomass condition has been organized at the reference plots in the Volzhsky industrial area. Monitoring comprises periodic inspection of reference plots and sampling reed biomass for analysis.

\section{Basic process parameters affecting the pellet quality}

In the course of producing pilot batches of reed fuel pellets, the main factors affecting their quality have been established: the moisture content of chips, the chip size, and the die shaft torque.

Among the factors listed, the initial moisture content of chips has the greatest impact on the pellet quality. When granulating reed biomass at the moisture content of the feedstock exceeding 15-20\%, the resulting fuel pellets are destructed by the internal pressure of water formed at the compression of the crushed mass. Therefore, in this case, the raw materials used to produce fuel pellets should be dried to a suitable moisture value. Since drying is the most energy-intensive operation in the fuel pellet production (up to $70 \%$ of the energy consumption falls on drying biomass [5]), the acceptance control allows optimizing the reed fuel pellet production process through the drying of only the feedstock whose moisture does not meet the standard requirements.

Determining the moisture content of the mowed reed biomass is important for other reasons as well. Firstly, when long-term storing the mowed reed biomass to be used as a raw material in the fuel pellet production, an increase in the moisture content of raw 
materials during storage to $15-20 \%$ and more creates the conditions for starting the vital activity of substrate microflora (bacteria, molds). The microflora activity is accompanied by a large biological heat release, the substrate is heated, and the process becomes even more active. The substrate begins to "burn". Secondly, with an initial biomass moisture content known, it is possible to choose the optimal operating conditions of the drying unit and determine the amount of water or steam required to moisturize raw material with too low initial moisture content. Thirdly, the relative moisture of the reed biomass was used to determine the dry biomass yield [6].

The moisture content of the reed samples from each plot was determined by two techniques-the analytical one and using the Wile Bio Wood moisture meter. The discrepancy between the values obtained using the instrument and the analytical technique did not exceed $5 \%$. Studying the impact of the moisture content of the reed chips on the possibility of granulating it and the quality of the pellets obtained allows establishing the following: at too low chip moisture content (less than $8 \%$ ), granulation does not virtually occur, the reed chips do not agglomerate and freely pour through the die holes; at a chip moisture content of 8-14\%, granulation occurs but the ungranulated mass yield is sufficiently large, such process cannot be considered effective and used for commercial purposes; herewith, an increase in the granulator operating time leads to the chip burning in the gap between the rollers and the die, which is accompanied by smoke, and the thermal effect is clearly visible on the pellet surface; such process is dangerous from the point of view of the possible chip burning in the granulator and the occurrence of a fire; the chip moisture content within 14-20\% may be considered optimal, the pellet yield and quality reach the highest values; with a further increase in moister content (over $20 \%$ ), the pellet quality deteriorates due to excessive water in it, which deforms the pellet when the latter leaves the die, the defects in the form of cracks are clearly visible on the pellet surface, and it remains brittle after cooling (Fig. 1).

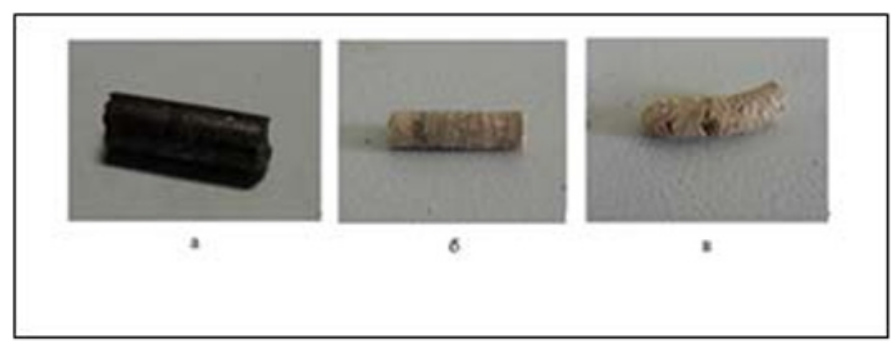

Fig. 1. Fuel Pellet: a) with a burnt surface; b) on-spec fuel pellet; c) defective pellet due to an excessive moisture content of raw material

It should be noted that in the course of granulation in a granulator with a flat rotating die and pressure rollers, the moisture content of the feedstock changes significantly. In the experiment, the granulator was fed with chips having a moisture content of $19.4 \%$. In the gap between the rollers and the die, a significant amount of heat is released, the pressed chips are heated, and their moisture content decreases. The heating of the pressed material continues as it passes through the die holes. At the die outlet, the pellets have a moisture content of $12.1 \%$ and an elevated temperature. During cooling, the moisture content of pellets decreases to $8.1 \%$. Thus, in the course of granulation, the moisture content of the material decreases almost 2.4 times from 19.4 to $8.1 \%$ that should be considered when developing an industrial process.

The impact of the initial chip moisture content on the pellet density has been established. For the experiment, pellets made of the fine chip with a moisture content of 10 , 20, and $25 \%$ were sampled. As can be seen from the diagram in Fig. 2, when the chip 
moisture content deviates from the optimal value, the pellet density decreases and the quality deteriorates [1].

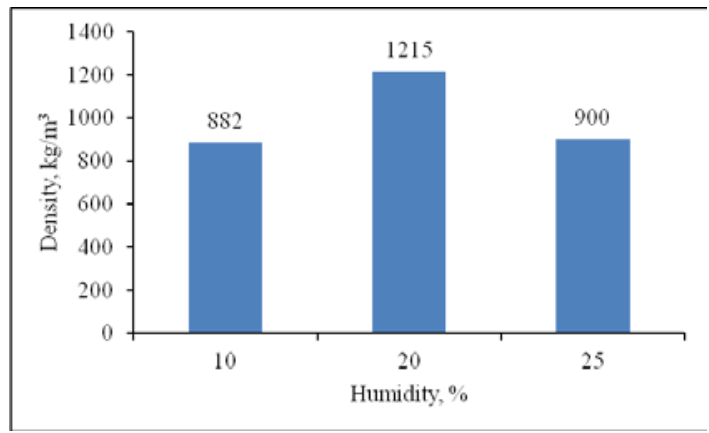

Fig. 2. Dependence of the Pellet Density on the Initial Moisture Content of Chips

Improving the pellet quality without changing the granulation conditions can be achieved by adding auxiliary components-binders to the chips. When choosing one or another binder, its cost, availability, and technological and environmental properties should be considered. In [7], the authors propose the following substances as binders: lignin, glycerin, stearin, and sodium stearate.

When testing the reed pellets obtained, potato starch was also used as a binding component. According to qualitative analysis, pellet samples in which potato starch was used as a binder showed good adhesion of the feedstock during compression and therefore, the highest density and strength. Also, it is worth noting that starch is the cheapest of the binders studied.

Estimating the reed fuel pellet quality was performed according to ISO 17225-6: 2014 "Solid biomass fuels (biofuels)-Fuel specifications and classes-Part 6: Graded non-woody pellets." According to the standard specified, the following indicators were studied: moisture content, \%; ash content, \%; calorific value (lower), $\mathrm{MJ} / \mathrm{kg}$; and the content of macro and microelements in their composition [8]. The moisture, ash, and the macro and microelements content studies were carried out in the Teplotekhnik Test Center; the test results are given in Table 2.

Table 2. Reed fuel pellet test results

\begin{tabular}{|l|c|}
\hline \multicolumn{1}{|c|}{ Indicator } & Analytical sample, \% wt. \\
\hline Moisture content & 9.20 \\
\hline Ash content & 6.14 \\
\hline Sulfur content & 0.08 \\
\hline Carbon content & 42.00 \\
\hline Hydrogen content & 5.10 \\
\hline Nitrogen content & 0.57 \\
\hline Oxygen content Microelements content, $\mathbf{m g} / \mathbf{k g}$ \\
\hline Lower calorific value, MJ/kg & 36.91 \\
\hline & 15.303 \\
\hline Vanadium & $<10$ \\
\hline Manganese & 387 \\
\hline Copper & 64 \\
\hline Arsenic & $<10$ \\
\hline Nickel & $<10$ \\
\hline Lead & 13 \\
\hline Strontium & 277 \\
\hline Chrome & 23 \\
\hline Zinc & 1674 \\
\hline Chlorine & 116 \\
\hline
\end{tabular}


Table 3 shows the elementary composition of the mineral (ash) part of the reed fuel pellets [9].

Table 3. Elementary composition of the mineral (ash) part of reed

\begin{tabular}{|c|c|}
\hline Indicator & Elementary Composition of Mineral Part, \% wt. \\
\hline $\mathrm{SiO}_{2}$ & 90.83 \\
\hline $\mathrm{TiO}_{2}$ & 0.03 \\
\hline $\mathrm{Al}_{2} \mathrm{O}_{3}$ & 0.35 \\
\hline $\mathrm{Fe}_{2} \mathrm{O}_{3}$ & 0.98 \\
\hline $\mathrm{CaO}$ & 2.44 \\
\hline $\mathrm{MgO}$ & 0.80 \\
\hline $\mathrm{K}_{2} \mathrm{O}$ & 2.90 \\
\hline $\mathrm{Na}_{2} \mathrm{O}$ & 0.84 \\
\hline $\mathrm{P}_{2} \mathrm{O}_{5}$ & 0.81 \\
\hline $\mathrm{SO}_{3}$ & 0.02 \\
\hline $\mathrm{Total}$ & 100.00 \\
\hline
\end{tabular}

The study results showed the possibility of using reeds to produce fuel pellets. The most suitable raw material is reed growing in relatively favorable environmental conditions, away from industrial enterprises. Reed beds located in the Volga-Akhtuba Floodplain natural park, as well as in the Svetloyarsky district of the Volgograd region and the Chernoyarsky district of the Astrakhan region meet these conditions; the largest and most promising from the reed harvesting and processing point of view beds are located in these areas.

\section{Conclusions}

1. During the expeditions, an area of about $10,000 \mathrm{~km} 2$ was surveyed on the territory of three districts of the Volgograd region and two districts of the Astrakhan region, where more than 16,000 ha of reed beds were identified.

2. To determine the productivity and the possible volumes of reed harvesting for the commercial beds located during the field research, the plot harvesting technique has been used.

3. The results of processing the experimental data obtained during the control mowing in the plots entirely confirm the initial assumption that the average reed yield is about $5 \mathrm{t} / \mathrm{ha}$. The average mowed and dry biomass yield is 5.7 and $4.6 \mathrm{t} / \mathrm{ha}$, respectively.

4. The forecasted total value of possible harvesting for all explored commercial reed beds is supposed to be within 75 to 85 thousand tons, which is quite enough to power an enterprise for processing agricultural products or arrange the production of reed pellets for sale on the solid biofuel market.

5. It has been established that the main parameter affecting the fuel pellet quality is the initial moisture content of chips, which is within 14 to $20 \%$.

6. It has been established that potato starch is the most suitable binder for the fuel pellet production, since it evenly spreads over the volume, increases the mixture's ability to agglomerate, reduces friction losses due to internal lubrication and thereby, improves the pellet quality.

7. By their main parameters, the fuel pellets obtained in the course of work fully comply with the standard ISO 17225-6: 2014 "Solid biomass fuels (biofuels)-Fuel specifications and classes-Part 6: Graded non-woody pellets.” 


\section{References}

1. L. V. Melinova, A. N. Soboleva V. F. Kablov, V. E. Kostin, N. A. Sokolova, L. G. Mamieva, N. A. Melinova, Energetik, 12 (2015)

2. http://www.infobio.ru (ref. date 11.12.2019).

3. N. A. Sokolova, V. E Kostin, V. G. Kochetkov and I. I. Vasenev, Proceedings of the International Scientific Conference of Young Scientists and Experts Dedicated to the 150th Anniversary of Leontovich A.V. (Moscow, June 03-06, 2019), K. A. Timiryazev Moscow Agricultural Academy, Moscow, 2019, pp. 126-130.

4. Paist, A. Proceedings of the 15th European biomass conference \& exhibition, Berlin, Germany

5. A. N. Barmin and V. B. Golub, Bulletin of the Samara Scientific Center of the Russian Academy of Sciences 2 (2000)

6. L. B. Dmitruk and V. V. Ivanovsky Rational Use and Protection of Plant Resources: Teaching Materials (Vitebsk: P.M. Masherov VSU, 2013)

7. S. Peredery, LesPromInform, 4 (2010)

8. Standard ISO 17225-6: 2014 "Solid biomass fuels (biofuels)-Fuel specifications and classes-Part 6: Graded non-woody pellets”.

9. $\quad$ N. A. Sokolova, V. E. Kostin and L. V. Melinova Energetik, 11 (2014) 